\title{
Epilepsy Syndromes in the First Year of Life and Usefulness of Genetic Testing for Precision Therapy
}

\author{
Allan Bayat ${ }^{1,2, *(\mathbb{D})}$, Michael Bayat ${ }^{3,4}$, Guido Rubboli ${ }^{2,5}$ and Rikke S. Møller ${ }^{1,2}$ \\ 1 Department of Regional Health Research, University of Southern Denmark, DK-5230 Odense, Denmark; \\ rimo@filadelfia.dk \\ 2 Danish Epilepsy Centre, Department of Epilepsy Genetics and Personalized Medicine, \\ DK-4293 Dianalund, Denmark; guru@filadelfia.dk \\ 3 Department of Clinical Genetics, University Hospital of Aarhus, DK-8200 Aarhus, Denmark; \\ bayat86@hotmail.com \\ 4 Department of Neurology, University Hospital of Aarhus, DK-8200 Aarhus, Denmark \\ 5 Institute of Clinical Medicine, University of Copenhagen, DK-1165 Copenhagen, Denmark \\ * Correspondence: abaya@filadelfia.dk
}

Citation: Bayat, A.; Bayat, M.; Rubboli, G.; Møller, R.S. Epilepsy Syndromes in the First Year of Life and Usefulness of Genetic Testing for Precision Therapy. Genes 2021, 12, 1051. https://doi.org/10.3390/ genes12071051

Academic Editor: Mariarosa Anna Beatrice Melone

Received: 18 May 2021

Accepted: 5 July 2021

Published: 8 July 2021

Publisher's Note: MDPI stays neutral with regard to jurisdictional claims in published maps and institutional affiliations.

Copyright: (c) 2021 by the authors. Licensee MDPI, Basel, Switzerland. This article is an open access article distributed under the terms and conditions of the Creative Commons Attribution (CC BY) license (https:/ / creativecommons.org/licenses/by/ $4.0 /)$.

\begin{abstract}
The high pace of gene discovery has resulted in thrilling advances in the field of epilepsy genetics. Clinical testing with comprehensive gene panels, exomes, or genomes are now increasingly available and have led to a significant higher diagnostic yield in early-onset epilepsies and enabled precision medicine approaches. These have been instrumental in providing insights into the pathophysiology of both early-onset benign and self-limited syndromes and devastating developmental and epileptic encephalopathies (DEEs). Genetic heterogeneity is seen in many epilepsy syndromes such as West syndrome and epilepsy of infancy with migrating focal seizures (EIMFS), indicating that two or more genetic loci produce the same or similar phenotypes. At the same time, some genes such as $S C N 2 A$ can be associated with a wide range of epilepsy syndromes ranging from self-limited familial neonatal epilepsy at the mild end to Ohtahara syndrome, EIFMS, West syndrome, Lennox-Gastaut syndrome, or unclassifiable DEEs at the severe end of the spectrum. The aim of this study was to review the clinical and genetic heterogeneity associated with epilepsy syndromes starting in the first year of life including: Self-limited familial neonatal, neonatal-infantile or infantile epilepsies, genetic epilepsy with febrile seizures plus spectrum, myoclonic epilepsy in infancy, Ohtahara syndrome, early myoclonic encephalopathy, West syndrome, Dravet syndrome, EIMFS, and unclassifiable DEEs. We also elaborate on the advantages and pitfalls of genetic testing in such conditions. Finally, we describe how a genetic diagnosis can potentially enable precision therapy in monogenic epilepsies and emphasize that early genetic testing is a cornerstone for such therapeutic strategies.
\end{abstract}

Keywords: epilepsy genetics; diagnostic yield; early-onset epilepsy; epileptic encephalopathy; benign and self-limiting (familial) epilepsy syndromes; precision therapy

\section{Introduction}

Although epilepsy can result from factors such as stroke, asphyxia, infections, autoimmune disorders, trauma, and tumors, a significant number of subjects with epilepsy are thought to have an underlying genetic factor [1]. Recent developments in molecular genetics have improved our understanding of the genetic causes, contributors, and modifiers of epilepsy. Next-generation sequencing has led to an explosion of gene discoveries in human disorders and up to 50\% of monogenic epilepsies reach a precision diagnosis [2]. The highest diagnostic yield is usually amongst subjects with early-onset seizures and a global neurodevelopmental delay [3,4]. New techniques that enable investigation of the epigenetic regulation and longer read lengths [2] combined with functional testing of variants of unknown significance, even in known genes, and systematic match-making 
exchange [5] are needed to facilitate a genetic diagnosis for the remaining half. The incidence of epilepsy is high during the first year and then declines throughout childhood [6]. The clinical pictures and prognoses of early-onset monogenic epilepsy syndromes are diverse and include both benign and self-limited (familial) epilepsy syndromes as well as devastating developmental and epileptic encephalopathies. Genetic testing is essential for determining precision medicine strategies and to prevent unnecessary and potentially harmful diagnostic procedures and managements. A genetic diagnosis can also provide useful information on the natural history and prognosis of a disease and facilitate more targeted genetic counseling. Furthermore, it allows the subject and their family to enter gene-specific networks of families with the same condition.

We review the phenotypic spectrum and genetic landscape of electroclinical epilepsy syndromes that begin during the first year of life (Table 1). We also discuss the utility of different genetic test strategies and provide examples of how genetic testing can enable precision therapy approaches in monogenic disorders.

Table 1. Epilepsy syndromes with onset during the neonatal period and/or infancy and the commonly associated genes (list is not exhaustive). The most commonly occurring genes within each electroclinical syndromes are listed first with percentages in bracket followed by less commonly occurring genes listed in alphabetic order and according to inheritance.

\begin{tabular}{|c|c|c|c|c|}
\hline \multicolumn{2}{|c|}{ Epilepsy Syndrome } & Gene Involved & Protein Product & $\begin{array}{l}\text { Mode of } \\
\text { Inheritance }\end{array}$ \\
\hline \multirow{11}{*}{$\begin{array}{c}\text { Benign } \\
\text { familial } \\
\text { epilepsy syndromes }\end{array}$} & \multirow{2}{*}{ BFNE } & KCNQ2 & Subunit of voltage-gated $\mathrm{K}+$ channel & $\mathrm{AD}$ \\
\hline & & KCNQ3 & Subunit of voltage-gated $\mathrm{K}+$ channel & $\mathrm{AD}$ \\
\hline & BFNIE & SCN2A & Subunit of voltage-gated $\mathrm{Na}+$ channel & $\mathrm{AD}$ \\
\hline & \multirow{3}{*}{ BFIE } & PRRT2 & Protein-rich transmembrane protein 2 & $\mathrm{AD}$ \\
\hline & & $S C N 2 A$ & Subunit of voltage-gated $\mathrm{Na}+$ channel & $\mathrm{AD}$ \\
\hline & & $S C N 8 A$ & Subunit of voltage-gated $\mathrm{Na}+$ channel & $\mathrm{AD}$ \\
\hline & \multirow{4}{*}{ GEFS+ } & SCN1A & Subunit of voltage-gated $\mathrm{Na}+$ channel & $\mathrm{AD}$ \\
\hline & & $S C N 1 B$ & Subunit of voltage-gated $\mathrm{Na}+$ channel & $\mathrm{AD}, \mathrm{AR}$ \\
\hline & & GABRG2 & Subunit of GABAa receptor & $\mathrm{AD}$ \\
\hline & & STX1B & Syntaxin 1B & $\mathrm{AD}$ \\
\hline & $\begin{array}{c}\text { Myoclonic } \\
\text { epilepsy in infancy }\end{array}$ & Unknown & - & - \\
\hline & \multirow{12}{*}{$\begin{array}{l}\text { Ohtahara } \\
\text { syndrome }\end{array}$} & STXBP1 (in 30\%) & Syntaxin binding protein 1 & $\mathrm{AD}$ \\
\hline & & KCNQ2 (in 20\%) & Subunit of voltage-gated $\mathrm{K}+$ channel & $\mathrm{AD}$ \\
\hline & & SCN2A (in $\sim 10 \%$ ) & Subunit of voltage-gated $\mathrm{Na}+$ channel & $\mathrm{AD}$ \\
\hline & & GNAO1 & $\begin{array}{l}\text { Guanine nucleotide-binding protein, } \\
\alpha \text {-activating activity polypeptide } \mathrm{O}\end{array}$ & $\mathrm{AD}$ \\
\hline & & KCNT1 & Subunit of voltage-gated $\mathrm{K}+$ channel & $\mathrm{AD}$ \\
\hline & & SNC8A & Subunit of voltage-gated NA+ channel & $\mathrm{AD}$ \\
\hline & & SIK1 & Salt-inducable kinase 1 & $\mathrm{AD}$ \\
\hline & & AARS & Alanyl-tRNA synthetase 1 & $\mathrm{AR}$ \\
\hline & & BRAT1 & BRACT1-associated atm activator 1 & AR \\
\hline & & CACNA2D2 & $\begin{array}{l}\text { Calcium channel, voltage-dependent, } \\
\qquad \alpha-2 / \text { delta subunit } 2\end{array}$ & $\mathrm{AR}$ \\
\hline & & NECAP1 & $\begin{array}{l}\text { NECAP endocytosis-associated } \\
\text { protein } 1\end{array}$ & AR \\
\hline & & PIGQ & $\begin{array}{l}\text { Phosphatidylinositol glycan anchor } \\
\text { biosynthesis class Q protein }\end{array}$ & $\mathrm{AR}$ \\
\hline
\end{tabular}


Table 1. Cont

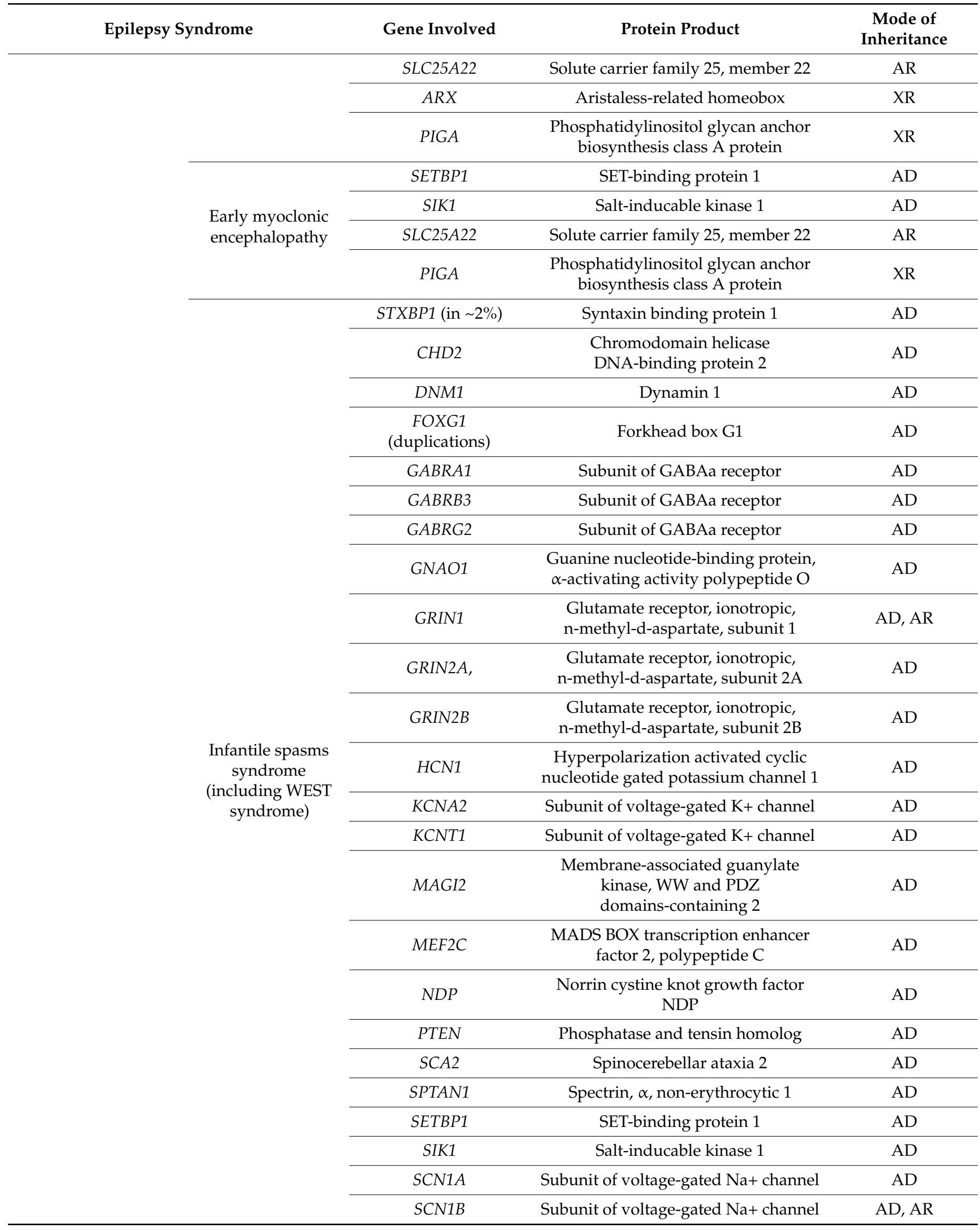


Table 1. Cont.

\section{Epilepsy Syndrome}

Gene Involved

Protein Product

Mode of Inheritance

\begin{tabular}{|c|c|}
\hline SCN2A & Subunit of voltage-gated $\mathrm{Na}+$ channel \\
\hline$S C N 8 A$ & Subunit of voltage-gated $\mathrm{Na}+$ channel \\
\hline SCN9A & Subunit of voltage-gated $\mathrm{Na}+$ channel \\
\hline STXBP1 & Syntaxin binding protein 1 \\
\hline TCF4 & Transcription factor 4 \\
\hline TSC1 & Tuberous sclerosis complex 1 \\
\hline TSC2 & Tuberous sclerosis complex 2 \\
\hline DOCK7 & Dedicator of cytokinesis 7 \\
\hline NRXN1 & Neurexin 1 \\
\hline PIGN & $\begin{array}{l}\text { Phosphatidylinositol glycan anchor } \\
\text { biosynthesis class N protein }\end{array}$ \\
\hline PIGP & $\begin{array}{l}\text { Phosphatidylinositol glycan anchor } \\
\text { biosynthesis class P protein }\end{array}$ \\
\hline PIGQ & $\begin{array}{l}\text { Phosphatidylinositol glycan anchor } \\
\text { biosynthesis class Q protein }\end{array}$ \\
\hline
\end{tabular}

\begin{tabular}{ccc}
\hline PIGS & $\begin{array}{c}\text { Phosphatidylinositol glycan anchor } \\
\text { biosynthesis class S protein }\end{array}$ & AR \\
\hline PLCB1 & Phospholipase C, $\beta$-1 & AR \\
\hline SLC25A22 & Solute carrier family 25, member 22 & AR \\
ST3GAL3 & $\begin{array}{c}\text { ST3 } \beta \text {-galactoside } \\
\alpha-2,3-\text { sialyltransferase 3 }\end{array}$ & AR \\
\hline TBC1D24 & TBC1 domain family, member 24 & AR \\
WWOX & WW domain-containing & AR \\
\hline CDKL5 & Cyclin-dependent kinase-like 5 & XD \\
\hline ARX & Aristaless-related homeobox & XR \\
PIGA & $\begin{array}{c}\text { Phosphatidylinositol glycan anchor } \\
\text { biosynthesis class A protein }\end{array}$ & XR \\
\hline ALG13 & $\begin{array}{c}\text { ALG13 UDP-N- } \\
\text { acetylglucosaminyltransferase } \\
\text { subunit }\end{array}$ & XL \\
\hline
\end{tabular}

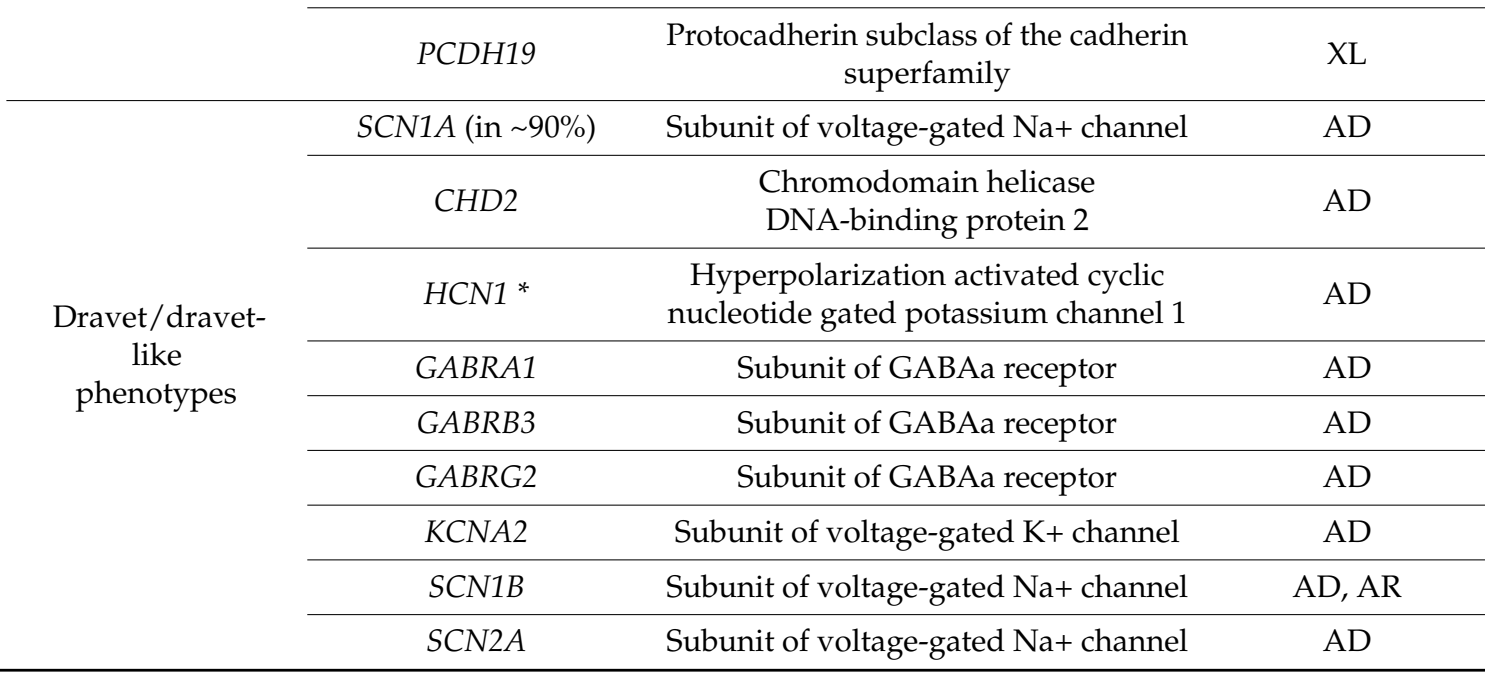


Table 1. Cont.

\begin{tabular}{|c|c|c|c|}
\hline Epilepsy Syndrome & Gene Involved & Protein Product & $\begin{array}{c}\text { Mode of } \\
\text { Inheritance }\end{array}$ \\
\hline & SCN8A & Subunit of voltage-gated $\mathrm{Na}+$ channel & $\mathrm{AD}$ \\
\hline & SCN9A & Subunit of voltage-gated $\mathrm{Na}+$ channel & $\mathrm{AD}$ \\
\hline & STXBP1 & Syntaxin binding protein 1 & $\mathrm{AD}$ \\
\hline & PCDH19 * & $\begin{array}{l}\text { Protocadherin subclass of the cadherin } \\
\text { superfamily }\end{array}$ & $\mathrm{XL}$ \\
\hline & KCNT1 (in 27\%) & Subunit of voltage-gated $\mathrm{K}+$ channel & $\mathrm{AD}$ \\
\hline & $S C N 2 A($ in $~ 7 \%)$ & Subunit of voltage-gated $\mathrm{Na}+$ channel & $\mathrm{AD}$ \\
\hline & SCN1A & Subunit of voltage-gated $\mathrm{Na}+$ channel & $\mathrm{AD}$ \\
\hline & GABRA1 & Subunit of GABAa receptor & $\mathrm{AD}$ \\
\hline & GABRB1 & Subunit of GABAa receptor & $\mathrm{AD}$ \\
\hline & GABRB3 & Subunit of GABAa receptor & $\mathrm{AD}$ \\
\hline & HCN1 & $\begin{array}{c}\text { Hyperpolarization-activated cyclic } \\
\text { nucleotide-gated potassium channel } 1\end{array}$ & $\mathrm{AD}$ \\
\hline & KCNQ2 & Subunit of voltage-gated $\mathrm{K}+$ channel & $\mathrm{AD}$ \\
\hline & $S C N 8 A$ & Subunit of voltage-gated $\mathrm{Na}+$ channel & $\mathrm{AD}$ \\
\hline & ATP1A3 & $\begin{array}{c}\text { ATPase, } \mathrm{Na}+/ \mathrm{K}+\text { transporting, } \alpha-3 \\
\text { polypeptide }\end{array}$ & $\mathrm{AD}$ \\
\hline \multirow[t]{13}{*}{ EIMFS } & AIMP1 & $\begin{array}{l}\text { Aminoacyl-tRNA synthetase } \\
\text { complex-interacting multifunctional } \\
\text { protein } 1\end{array}$ & $\mathrm{AR}$ \\
\hline & BRAT1 & BRCA1-associated ATM activator 1 & $\mathrm{AR}$ \\
\hline & ITPA & Inosine triphosphatase & $\mathrm{AR}$ \\
\hline & KARS & Lysyl-tRNA synthetase 1 & $\mathrm{AR}$ \\
\hline & PLCB1 & Phospholipase $C, \beta-1$ & $\mathrm{AR}$ \\
\hline & QARS & Glutaminyl-tRNA synthetase 1 & $\mathrm{AR}$ \\
\hline & SLC12A5 & Solute carrier family 12 & $\mathrm{AR}$ \\
\hline & SLC25A22 & Solute carrier family 25, member 22 & $\mathrm{AR}$ \\
\hline & TBC1D24 & TBC1 domain family, member 24 & $\mathrm{AR}$ \\
\hline & WWOX & $\begin{array}{l}\text { WW domain-containing } \\
\text { oxidoreductase }\end{array}$ & $\mathrm{AR}$ \\
\hline & CDKL5 & Cyclin-dependent kinase-like 5 & $\mathrm{XD}$ \\
\hline & $S M C 1 A$ & $\begin{array}{l}\text { Structural maintenance of } \\
\text { chromosomes } 1 \mathrm{~A}\end{array}$ & $\mathrm{XD}$ \\
\hline & PIGA & $\begin{array}{l}\text { Phosphatidylinositol glycan anchor } \\
\text { biosynthesis class A protein }\end{array}$ & $\mathrm{XR}$ \\
\hline
\end{tabular}

Abbreviations: $\mathrm{AD}=$ autosomal dominant; $\mathrm{AR}=$ autosomal recessive; $\mathrm{BFIE}=$ benign familial infantile epilepsy; $\mathrm{BFNE}=$ benign familial neonatal epilepsy; BFNIE = benign familial neonatal infantile epilepsy; BRCT1 = breast cancer associated ATM activator 1; EIMFS = early infantile migrating focal seizures; GABA $=\gamma$ aminobutyric acid; GEFS $+=$ genetic epilepsy with febrile seizures plus; $\mathrm{XD}=\mathrm{X}$-linked dominant; $\mathrm{XL}=\mathrm{X}$-linked; $\mathrm{XR}=\mathrm{X}$-linked recessive. ${ }^{*} \mathrm{In}$ most subjects, the syndrome is distinguishable from Dravet syndrome.

\section{Benign and Self-Limited (Familial) Epilepsy Syndromes in Infancy}

In these syndromes, de novo and inherited pathogenic variants produce broadly similar electroclinical features in both familial and non-familial cases. Therefore, the inheritance is assigned as a secondary denominator and is placed in parenthesis. Five benign epilepsy syndromes are recognized in infancy: Benign (familial) neonatal epilepsy (BFNE), benign 
(familial) neonatal-infantile epilepsy (BFNIE), benign (familial) infantile epilepsy (BFIE), genetic epilepsy with febrile seizures plus (GEFS+) spectrum, and myoclonic epilepsy in infancy [7-9]. All syndromes typically occur in previously healthy children with ageappropriate development, examination, and head circumference. Development, cognition, and interictal electroencephalograms (EEGs) are normal, and subjects respond well to antiseizure medications [7]. While these syndromes are typically considered to be self-limiting this may not always be the case.

\subsection{Benign (Familial) Neonatal Epilepsy}

BFNE is a condition characterized by recurrent seizures in otherwise healthy newborn babies. The seizures begin around day 5 of life and usually remit by the end of the first year [10]. Subjects display normal neuropsychological development and EEG recordings. BFNE is a genetically heterogeneous disorder due to loss-of-function variants in the KCNQ2 or KCNQ3 genes. These two genes encode voltage-gated potassium channel subunits Kv7.2 and Kv7.3.7 [10,11]. Unprovoked focal onset motor seizures that evolve to bilateral tonicclonic seizures are the predominant seizure type, and they are occasionally associated with non-motor symptoms such as staring, apnea, and cyanosis [7]. Historically, the percentage of children with BFNE who experience subsequent (i.e., post-infantile) focal or generalized seizures has been thought to be $10-18 \%[10,12,13]$. Seizures re-occur in different age groups spanning from early childhood to adulthood, with most events in childhood being induced by fever and most seizures in adolescence and adulthood being afebrile [13].

\subsection{Benign (Familial) Neonatal-Infantile Epilepsy}

BFNIE occurs between the first day and 7 months of life (mean 11 weeks), and symptoms tend to remit by the end of the first year (17). Symptoms resemble BFNE, and the overlap in age at seizure onset makes genetic testing crucial. BFNIE is often caused by a missense variant in $S C N 2 A$ encoding voltage-gated sodium channel subunits $\mathrm{Na}_{\mathrm{v}} 1.2$ and leading to a gain-of-function $(\mathrm{GoF})$, thereby causing increased neuronal excitability $[14,15]$.

\subsection{Benign (Familial) Infantile Epilepsy}

BFIE occurs between 3 and 8 months of age, with clusters (8-10 per day) of repeated and brief episodes ( $2-5 \mathrm{~min}$ ) over a few days [7]. Seizures remit spontaneously before the age of 3 years [16,17]. They are usually focal but can sometimes become generalized. Subjects present with motor arrest, unresponsiveness, head and/or eye deviation to one side, staring, fluttering of eyelids, grunting, cyanosis, diffuse hypertonia, and unilateral or bilateral clonic jerks of the limbs. Seizures are rarely observed later in life, although some subjects develop paroxysmal movement disorders such as paroxysmal dyskinesia, paroxysmal kinesigenic choreoathetosis, hemiplegic migraine, and episodic ataxia during adolescence [18].

BFIE is a genetically heterogeneous disease $[19,20]$. Most cases are associated with variants in the proline-rich transmembrane protein 2 (PRRT2) gene located at 16p11.2 [21,22]. PRRT2 accounts for up to $70 \%$ of BFIE families $[23,24]$. This gene encodes a membrane protein that interacts with the presynaptic protein synaptosomal-associated protein 25 (SNAP-25), which is involved in releasing neurotransmitters from synaptic vesicles [25]. Variants have also been found in SCN2A, SCN8A (encoding the voltage-gated sodium channel subunits $\mathrm{Na}_{\mathrm{v}} 1.6$ ) [26], and on rare occasions in the KCNQ2 and KCNQ3 gene [20]. The overlapping phenotypes of these three syndromes make it difficult to distinguish between them, making genetic testing crucial.

\subsection{GEFS+ Spectrum (Including Febrile Seizures Plus)}

The most common seizure type in GEFS+ is classical febrile seizures, which occur after age 6 months and typically do not persist beyond 6 years of age. In comparison, febrile seizures plus (FS+), which is the second most common phenotype, occur prior to age 6 months and persist beyond 6 years of age [27]. Afebrile seizure types such as absence, 
myoclonic seizures, and atonic seizures may develop at various ages [27]. Prolonged and recurrent hemiclonic/focal clonic seizures provoked by fever and occurring prior to 6-9 months of life should raise a suspicion of Dravet syndrome.

GEFS+ is a genetically heterogeneous disorder. SCN1A (encoding the voltage-gated sodium channel subunits $\mathrm{Na}_{\mathrm{v}} 1.1$ ) accounts for the largest fraction, with disease-causing variants detected in approximately $10-20 \%$ of families $[28,29]$. Other genes such as $G A B R A 1$, GABRB3, GABRG2, SCN1B, and STX1B have also been linked to the syndrome [28-32]. Although inheritance is usually autosomal dominant with variable expressivity and penetrance, de novo pathogenic variants have also been described [28].

DEEs, epilepsy with myoclonic-atonic seizures, and Dravet syndrome belong to the severe end of the GEFS+ spectrum. Intra-familial phenotypical heterogeneity has been reported and on rare occasions, some affected members of a GEFS+ family may evolve into this severe end of the spectrum [33]. Factors underlying the mechanism of pleiotropy are not fully understood but may involve variable expressivity of a single disease-causing gene, genetic modifiers, or epigenetic factors.

\subsection{Myoclonic Epilepsy in Infancy}

Myoclonic seizures are the hallmark of this syndrome and involve the head and the upper limbs. They are typically present both in wakefulness and sleep and may occur several times daily. Seizures may be triggered by sudden noise, touch, or startle [34]. Onset tends to be between the ages of 4 months and 3 years, with a peak age of 6-18 months [34]. Development prior to seizure onset is typically normal. Febrile seizures can either precede or follow myoclonic seizures [34]. Seizures tend to remit within 6 months to 5 years from onset, but approximately $10 \%$ develop other epilepsies in late childhood or adolescence, mostly juvenile myoclonic epilepsy [34]. Although causal genes have yet to be identified, a family history of epilepsy or febrile seizures is reported in approximately $10 \%$ of subjects [34].

\section{Developmental and Epileptic Encephalopathies (DEEs)}

The term epileptic encephalopathy is used for conditions associated with normal development prior to the onset of epileptic activity but where the epileptic activity "per se" causes a progressive brain dysfunction [35,36]. In "developmental encephalopathies" (DE), an underlying genetic condition causes neurological impairment without the epileptic activity associated with regression or further slowing of development [35,36]. Developmental encephalopathies are often accompanied by epilepsies but typically as few and treatable seizures where the epileptic activity does not impair development or cognition [35]. In DEEs, both the underlying genetic condition and the epileptic activity are considered to play a role $[35,36]$.

DEEs comprise a large, heterogeneous group of severe epilepsies characterized by early onset and treatment resistant epilepsy, multiple seizure types, frequent interictal epileptiform discharges on EEG, and developmental slowing or regression [37]. More than 100 genes including SCN1A, SCN2A, SCN8A, KCNA2, KCNB1, KCNQ2, KCNT1, CACNA1A, STXBP1, CDKL5, PCDH19, and SLC2A1 have been associated with earlyonset DEEs [37,38] (Tables 1 and 2-lists not exhaustive). While some genes just have a single phenotype, others have a varying phenotype depending on the subject's age and the nature of the causative variant(s). DEEs encompass several age-related electroclinical syndromes with specific seizure types and EEG features [37]. Ohtahara syndrome and early myoclonic encephalopathy are the earliest presenting of the epileptic encephalopathies and are also classified as early infantile DEEs. They are typically distinguished from each other according to specific clinical and etiologic criteria although considerable overlap exists [39]. 
Table 2. Genotype-phenotype relationship of the most recurrent genes associated with benign familial neonatal and/or infantile epilepsies and early-onset developmental and epileptic encephalopathies together with potential precision therapy approaches.

\begin{tabular}{|c|c|c|c|}
\hline Gene & Associated Epilepsy Syndromes & $\begin{array}{l}\text { Associated with Structural } \\
\text { Brain Anomalies/Lesions }\end{array}$ & Potential Therapeutic Approaches \\
\hline$A R X$ & $\begin{array}{l}\text { Ohtahara syndrome } \\
\text { Epileptic spasms syndrome } \\
\text { Myoclonic epilepsy } \\
\text { Nonsyndromic intellectual } \\
\text { disability with or without epilepsy } \\
\text { Developmental and epileptic } \\
\text { encephalopathy } 1\end{array}$ & Yes & Currently none available \\
\hline CDKL5 & $\begin{array}{l}\text { Epileptic spasms syndrome } \\
\text { Developmental and epileptic } \\
\text { encephalopathy } 2\end{array}$ & Yes & Ganaxolone (PMID 33165915) \\
\hline KCNA2 & $\begin{array}{l}\text { Developmental and epileptic } \\
\text { encephalopathy } 32 \\
\text { ESES }\end{array}$ & Yes & $\begin{array}{c}\text { GoF: } \\
\text { 4-Aminopyridine } \\
\text { Sodium channel blockers (PMID } \\
\text { 33515866) }\end{array}$ \\
\hline KCNB1 & $\begin{array}{l}\text { Developmental and epileptic } \\
\text { encephalopathy } 26 \\
\text { Epileptic spasms syndrome } \\
\text { ESES }\end{array}$ & Yes & Currently none available \\
\hline KCNQ2 & $\begin{array}{l}\text { Benign familial neonatal epilepsy } \\
\text { Ohtahara syndrome } \\
\text { Neonatal epileptic encephalopathy } \\
\text { EIMFS } \\
\text { Developmental and epileptic } \\
\text { encephalopathy } 7\end{array}$ & Yes & $\begin{array}{c}\text { LoF: } \\
\text { Sodium channel blockers } \\
\text { (PMID 24371303 and 25880994) } \\
\text { Retigabine (PMID 27602407) }\end{array}$ \\
\hline KCNQ3 & Benign familial neonatal epilepsy & Yes & $\begin{array}{c}\text { LoF: } \\
\text { Sodium channel blockers } \\
\text { (PMID 27888506) } \\
\text { Retigabine (PMID 27602407) }\end{array}$ \\
\hline KCNT1 & $\begin{array}{l}\text { Autosomal dominant sleep-related } \\
\text { hypermotor epilepsy } \\
\text { EIMFS } \\
\text { Developmental and epileptic } \\
\text { encephalopathy } 14\end{array}$ & Yes & $\begin{array}{c}\text { GoF: } \\
\text { Quinidine (PMID 31054119) }\end{array}$ \\
\hline PRRT2 & $\begin{array}{l}\text { Benign familial infantile epilepsy } \\
\text { Infantile convulsion and } \\
\text { choreoathetosis syndrome } \\
\text { Paroxysmal kinesigenic dyskinesia }\end{array}$ & Yes & Carbamazepine (PMID 32413583) \\
\hline SCN1A & $\begin{array}{l}\text { Dravet syndrome } \\
\text { Genetic epilepsy with febrile } \\
\text { seizure plus } \\
\text { EIMFS } \\
\text { Developmental and epileptic } \\
\text { encephalopathy } 6\end{array}$ & Yes & $\begin{array}{c}\text { Lof: } \\
\text { Stiripentol (+ valproate + clobazam) } \\
\text { Fenfluramine } \\
\text { Cannabidiol } \\
\text { Avoid sodium channel blockers } \\
\text { (PMID 32413583) }\end{array}$ \\
\hline$S C N 2 A$ & $\begin{array}{l}\text { Benign familial neonatal infantile } \\
\text { epilepsy } \\
\text { Genetic epilepsy with febrile } \\
\text { seizures plus } \\
\text { Epileptic spasms syndrome } \\
\text { EIMFS } \\
\text { Ohtahara syndrome } \\
\text { Developmental and epileptic } \\
\text { encephalopathy } 11\end{array}$ & Yes & $\begin{array}{c}\text { GoF: } \\
\text { Sodium channel blockers (PMID } \\
\text { 32413583) } \\
\text { LoF: } \\
\text { Avoid sodium channel blockers (PMID } \\
\text { 32413583) }\end{array}$ \\
\hline
\end{tabular}


Table 2. Cont.

\begin{tabular}{|c|c|c|c|}
\hline Gene & Associated Epilepsy Syndromes & $\begin{array}{l}\text { Associated with Structural } \\
\text { Brain Anomalies/Lesions }\end{array}$ & Potential Therapeutic Approaches \\
\hline$S C N 8 A$ & $\begin{array}{l}\text { Benign familial neonatal infantile } \\
\text { epilepsy } \\
\text { Developmental and epileptic } \\
\text { encephalopathy } 13\end{array}$ & Yes & $\begin{array}{c}\text { GoF: } \\
\text { Sodium channel blockers (PMID } \\
\text { 32413583) } \\
\text { LoF: } \\
\text { Avoid sodium channel blockers (PMID } \\
\text { 32413583) }\end{array}$ \\
\hline STXBP1 & $\begin{array}{l}\text { Ohtahara syndrome. } \\
\text { Epileptic spasms syndrome } \\
\text { Nonsyndromic intellectual } \\
\text { disability with or without epilepsy } \\
\text { Developmental and epileptic } \\
\text { encephalopathy } 4\end{array}$ & Yes & $\begin{array}{l}\text { Levetiracetam may have superior effect } \\
\text { on seizures and movement disorder } \\
\text { (PMID 29896790). }\end{array}$ \\
\hline SLC25A22 & $\begin{array}{l}\text { Ohtahara syndrome } \\
\text { Early myoclonic epilepsy } \\
\text { EIMFS } \\
\text { Developmental and epileptic } \\
\text { encephalopathy } 3\end{array}$ & Yes & Currently none available \\
\hline TSC1 & Epileptic spasms syndrome & Yes & $\begin{array}{l}\text { Everolimus and other mTOR inhibitors } \\
\text { (PMID 27351628) }\end{array}$ \\
\hline TSC2 & Epileptic spasms syndrome & Yes & $\begin{array}{l}\text { Everolimus and other mTOR inhibitors } \\
\text { (PMID 27351628) }\end{array}$ \\
\hline
\end{tabular}

Abbreviations: EIEE = early infantile epileptic encephalopathy; EIMFS = early infantile focal migrating seizure; ESES = electroclinical status epilepticus in sleep; GoF = gain-of-function; LoF = loss-of-function.

Before describing the electroclinical syndromes that start during the first year of life, we must emphasize that most DEEs do not fit well within any of these electroclinical syndromes and can at best only be categorized as unclassified DEEs.

\subsection{Ohtahara Syndrome}

Ohtahara syndrome is characterized by onset of intractable seizures during the first few weeks to months of life [40]. Infants acutely develop focal or generalized tonic spasms that often occur in clusters. Spasms typically last up to $10 \mathrm{~s}$ and can occur hundreds of times per day [40,41]. Approximately one-third of subjects with Ohtahara syndrome will also develop other seizure types, most commonly focal onset motor seizures or generalized tonicclonic seizures [40,42]. The EEG in Ohtahara syndrome indicates a burst suppression pattern, comprising bursts of high-amplitude spikes and polyspikes that alternate at a regular rate with periods of electric suppression [40]. The bursts coincide with the tonic spasms [43]. The prognosis is generally grave. Subjects with Ohtahara syndrome often die during infancy [42], and survivors invariably manifest a severe to profound psychomotor retardation [40,42]. Yamatogi and Ohtahara [42] showed that $75 \%$ of subjects later developed West syndrome, while $12 \%$ subsequently developed Lennox-Gastaut syndrome.

Structural brain anomalies, inborn errors of metabolism, and genetic abnormalities are amongst the causes of Ohtahara syndrome. To date, various genes that play essential roles in neuronal and interneuronal functions of the brain have been associated with Ohtahara syndrome $[37,40]$. Of these, syntaxin-binding protein 1 (STXBP1), which regulates the release of synaptic vesicles and the secretion of neurotransmitters, is the major contributor and explains $\sim 30 \%$ of cases $[38,44]$. Pathogenic variants in other genes include the voltage-gated potassium channel gene (KCNQ2) $(\sim 20 \%)[38,45]$; SCN2A, a gene encoding the voltage gated sodium channel $\mathrm{Na}_{\mathrm{v}} 1.2(\sim 10 \%)[38,46]$ aristaless-related homeobox $(A R X)$, a regulator of the proliferation and differentiation of neuronal progenitors [47]; solute carrier family 25 member 22 (SLC25A22), which encodes a mitochondrial glutamate 
transporter [48]; and potassium-activated channel subfamily T member 1 (KCNT1), which is widely expressed in the nervous system [49,50] (See Table 1 for additional genes).

While protein-truncating variants in KCNQ2 tend to cause benign familial epilepsy syndromes of infancy, missense variants may present with a distinct phenotype characterized by neonatal seizures that evolve to drug-resistant DEE and intellectual disability-KCNQ2related neonatal epileptic encephalopathy (KCNQ2-NEE) (Table 2) [10,45]—although this entity does not always fulfill the clinical criteria for Ohtahara syndrome.

Age of seizure onset and seizure type are similar to BFNE, but the seizures are resistant to therapy. EEGs show a burst-suppression pattern during the first few days of life, followed by multifocal epileptiform activities [10]. During childhood, most subjects suffer from profound intellectual disabilities and neurological abnormalities such as hypotonia or spastic quadriplegia [10,51]. The wide spectrum of seizure types encompasses tonic (often focal) or apneic episodes, focal clonic activity, and autonomic changes. Similar to the KCNQ2 variants, GoF SCN2A variants can also cause a spectrum of intractable childhood epilepsies ranging from Ohtahara syndrome and migrating focal seizures to epileptic spasms and Dravet syndrome [46]. The variants identified in intractable epilepsies alter the channel properties of $\mathrm{Na}_{\mathrm{v}} 1.2$ more than BFNIE variants do, suggesting the mechanism of more severe epileptic phenotypes [7,52].

\subsection{Early Myoclonic Encephalopathy}

Like Ohtahara syndrome, early myoclonic encephalopathy presents during the neonatal period-usually within the first 3 months of age, and sometimes as early as a few hours after birth. The initial presentation typically involves the onset of focal myoclonus, usually of the face or extremities. The jerks can shift from one area of the body to another in an asynchronous, seemingly random pattern. Tonic spasms are also frequent, occurring both isolated or in clusters [40]. The key EEG feature in early myoclonic encephalopathy comprises a suppression-burst pattern, much like that in Ohtahara syndrome [53]. However, in early myoclonic encephalopathy, the EEG pattern is either exclusively present or more distinct during sleep [53]. As in Ohtahara syndrome, the prognosis is poor with a high mortality and morbidity. Progressive, diffuse cortical atrophy is often present and suggestive of an underlying metabolic, degenerative, and/or genetic disorder $[40,41,53]$. The genes involved in this syndrome include the phosphatidylinositol glycan anchor biosynthesis class A (PIGA) involved in glycosylation [38,54,55], set-binding protein 1 (SETBP1) [38], salt-inducible kinase 1 (SIK1) [38,56], and SLC25A22 [38,48] (Table 1).

\subsection{Epileptic Spasms Syndrome and West Syndrome}

West syndrome refers to the constellation of epileptic spasms (also known as infantile spasms), hypsarrhythmia, and developmental impairment, often with regression. In some infants, the developmental impairment may not be apparent or typical hypsarrhythmia is not present. This is often seen in subjects with early diagnosis and treatment [57]. This emphasizes the importance of early diagnosis, where a short lag time to therapy can lead to a better outcome [57].

The spasms usually begin in the first 4 to 6 months of life and are characterized by clusters of flexion or extension limb and trunk spasms. Developmental regression is often present. Spasms may be observed as the infant awakes from or falls to sleep and are accompanied by the EEG pattern of hypsarrhythmia [58]. The pattern consists of random, high-voltage, nonsynchronous spikes and slow waves of variable duration and topography [58]. The major causes include acquired brain injuries, congenital brain malformations, inborn error of metabolism, and pathogenic genetic variants [58]. Pathogenic variants have been detected in over 30 genes $[7,38,59]$, and cyclin-dependent kinase-like 5 (CDKL5) $(\sim 10 \%)$, STXBP1 ( 2\%), and ARX are among the most commonly detected genes (See Table 1 for additional genes). Although epileptic spasm syndrome is very heterogeneous, TSC1 and TSC2 (encoding tuberous sclerosis complex 1 and 2 subunits) cause a syndrome that is easily recognizable due to the associated brain MRI features. 
Approximately $30 \%$ of cases remain unexplained, suggesting that many causative genes have yet to be identified [59-61].

\subsection{Dravet Syndrome (DS)}

In DS or "severe myoclonic epilepsy of infancy", healthy children typically develop seizures between the age of five to eight months $[7,62,63]$. Seizures may be triggered by fever, vaccination, stress, and bathing. Children experience prolonged hemiconvulsive or generalized febrile seizures during the first year of life [62,63]. This is followed by multiple types of intractable afebrile seizures, frequent occurrence of status epilepticus, and psychomotor retardation [63]. Interictal EEGs and brain imaging are usually normal at the time of onset, which often delays diagnosis. Although the vast majority of cases are caused by loss-of-function variants in SCN1A [64], other genes have also been reported to cause DS, including SCN2A, SCN8A, SCN9A, SCN1B, PCDH19, GABRA1, GABRG2, STXBP1, $H C N 1, C H D 2$, and KCNA2 [64] (Table 1). Symptoms associated with SCN1A range from GEFS+ at the mild end to DS at the severe end [64].

\subsection{Epilepsy of Infancy with Migrating Focal Seizures (EIMFS)}

EIMFS is a rare DEE characterized by seizure migration between cerebral hemispheres and profound developmental impairment, often with regression [65]. Onset of seizures is typically during the first six months of life, and seizures are refractory to antiepileptic drugs. Typical interictal EEG features include multifocal spikes with slow background activity [66] while a burst-suppression pattern occurs on rare occasions [67]. EIMFS is currently associated with pathogenic variants in 33 genes [65]. Both autosomal dominant and recessive patterns of inheritance have been described [65]. The most commonly involved genes are KCNT1 (in 27\%) and SCN2A (in 7\%) followed by SCN1A [65,68] (See Table 1 for additional genes). The genetic heterogeneity in EIMFS resembles that in other epileptic syndromes, such as epileptic spasms, but a considerably higher yield with current testing strategies has been described [65].

\section{Advantages and Pitfalls in Genetic Testing of Subjects with Onset of Epilepsy Syndromes during the First Year of Life}

Over the last decade, next-generation sequencing (NGS) has led to remarkable advances in the field of epilepsy genetics. It has become a powerful tool for genetic testing and provides the foundation for optimized genetic counseling. NGS is largely available in many countries as part of the routine diagnostic workup, resulting in higher diagnostic yields and greater insights into the underlying disease mechanisms. Several NGS technologies are currently available-targeted gene panels, whole-exome sequencing (WES), and whole-genome sequencing (WGS) (Figure 1).

Single-gene sequencing is indicated in subjects with a likely well-characterized monogenic disorder and should be avoided if the disorder demonstrates a high degree of genetic heterogeneity. It is the gold standard for detecting small sequence variations, but as only one gene is screened at a time, Sanger sequencing can become a time-consuming and expensive odyssey. In contrast, gene panels enable simultaneous testing of multiple genes associated with heterogeneous infantile epilepsy syndromes. Recent studies have shown an overall diagnostic yield of epilepsy gene panels ranging $15-48 \%$ [4,69-71], but the results vary according to phenotype. The highest yield is among subjects with neonatal-onset epilepsies and epileptic encephalopathies (57\%) [4]. Lindy et al. [69] evaluated the diagnostic outcomes from testing 70 genes in more than 8500 subjects with epilepsy and neurodevelopmental disorders. They used a gene panel combined with exon-level array comparative genomic hybridization (CGH) and found pathogenic or likely pathogenic variants in $15.4 \%$ of the subjects [69]. Although this was relatively low compared to previous studies, the results provide a robust estimate given the large subject cohort. In comparison, the diagnostic yield of WES is between $25 \%$ and $44 \%$ [72-74]. One disadvantage with gene panels is that they are restricted to the number of genes on a given panel and that 
disease-causing variants in unknown genes are missed, while WES covers the entire human coding sequence.
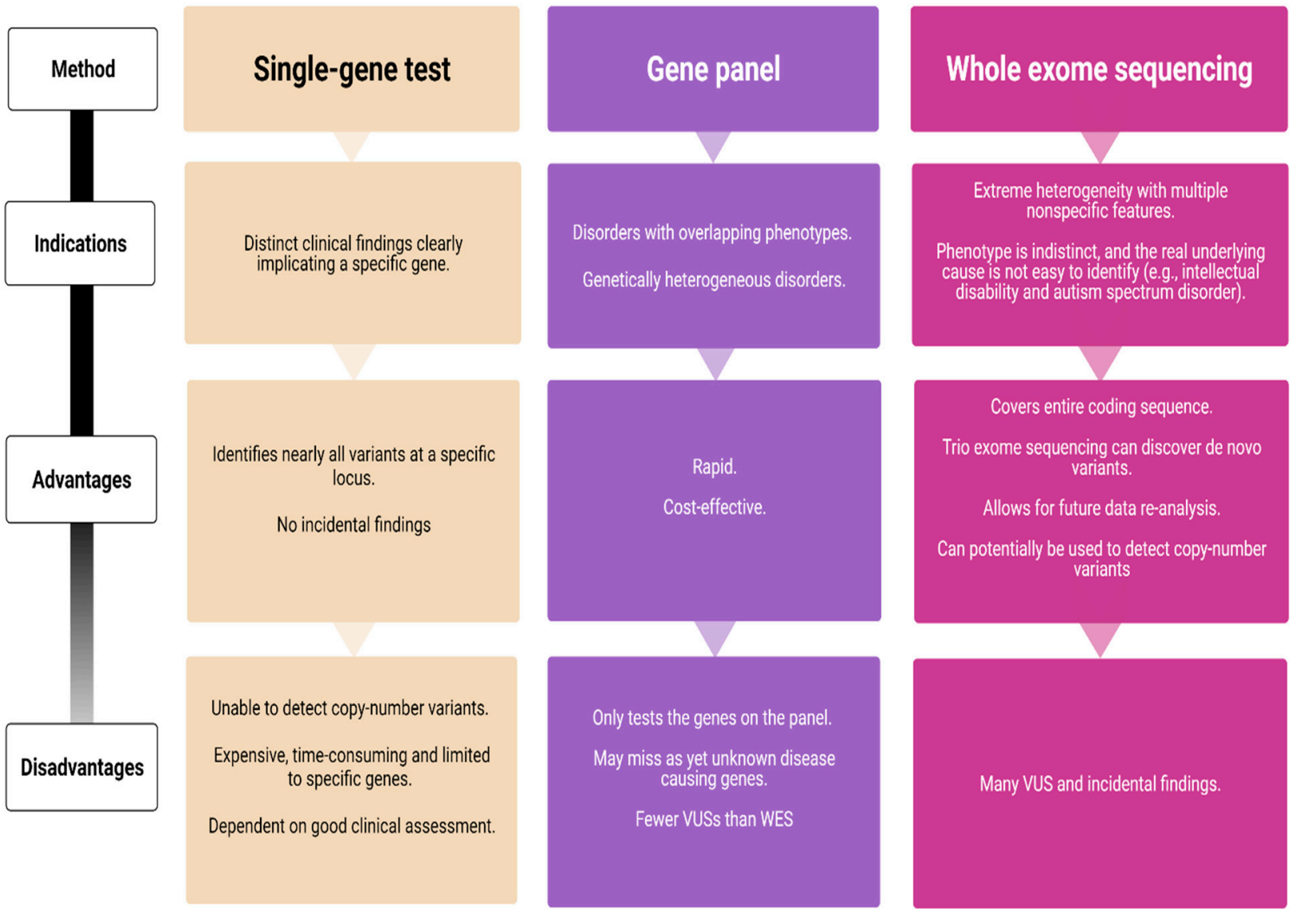

Figure 1. Comparison of genetic testing strategies (VUS = variant of unknown significance; WES = whole exome sequencing).

Between 5 and $10 \%$ of DEEs harbor a causative or potentially contributing copy number variant $(\mathrm{CNV})$ and chromosomal microarrays studies are considered a standard early investigation $[38,75]$ especially in exome negative subjects. CNVs may involve multiple genes and/or regulatory regions. Microdeletions and duplications can also represent as normal variants in the human karyotype, and pathogenecity must be ascertained once a $\mathrm{CNV}$ is detected. For this aim, several factors are taken into consideration: Segregation (as a CNV inherited from a healthy parent is less likely to be disease causing); presence of the $\mathrm{CNV}$ in the general population using gnomAD [76] or in affected subjects using gene variant databases such as ClinVar [77]; based on the function of genes contained by the $\mathrm{CNV}$; and finally the size of the $\mathrm{CNV}$ (as deletions larger than $1 \mathrm{Mb}$ are more likely to be causative) [38].

Although WES is not optimal for detecting CNVs, it has the potential to discover new genes-particularly when subjects have similar phenotypes that carry similar variants. A single WES or a larger gene panel increases the detection rate of variants of unknown significance (VUS), thus making parental testing, family-segregation analysis, and functional studies crucial. WES and WGS also pose a risk of detecting incidental but medically important findings that are unrelated to the indication for ordering the test. Targeted NGS requires confirmation using a second method, and complimentary Sanger sequencing is often required due to the low coverage of exons.

A clear advantage of WES/WGS is the possibility to re-analyze the data. As new epilepsy genes are constantly being discovered, many laboratories offer re-analysis after 
certain time intervals. A WES initially considered as uncertain or negative may yield a diagnosis after a period of 6-12 months [78].

Genetic testing as part of a routine diagnostic workup is also useful in adults or elderly subjects diagnosed with early-onset epilepsy $[79,80]$. Investigation of such cohorts have taught us that, even in adulthood, a precision diagnosis can lead to optimized therapeutic decision-making, improved seizure control, and potentially a better quality of life [80].

\section{Utility of Early Genetic Testing for Precision Therapy Approaches}

Treatment of epilepsy remains largely empirical and is often a trial and error rather than a targeted treatment approach (Figure 2). Early genetic testing lays the foundation for a precision diagnosis and thereby precision therapy, but it needs to be backed up by functional testing to provide pathogenicity and to explore the underlying functional effect of a given variant [81] (Figure 2).
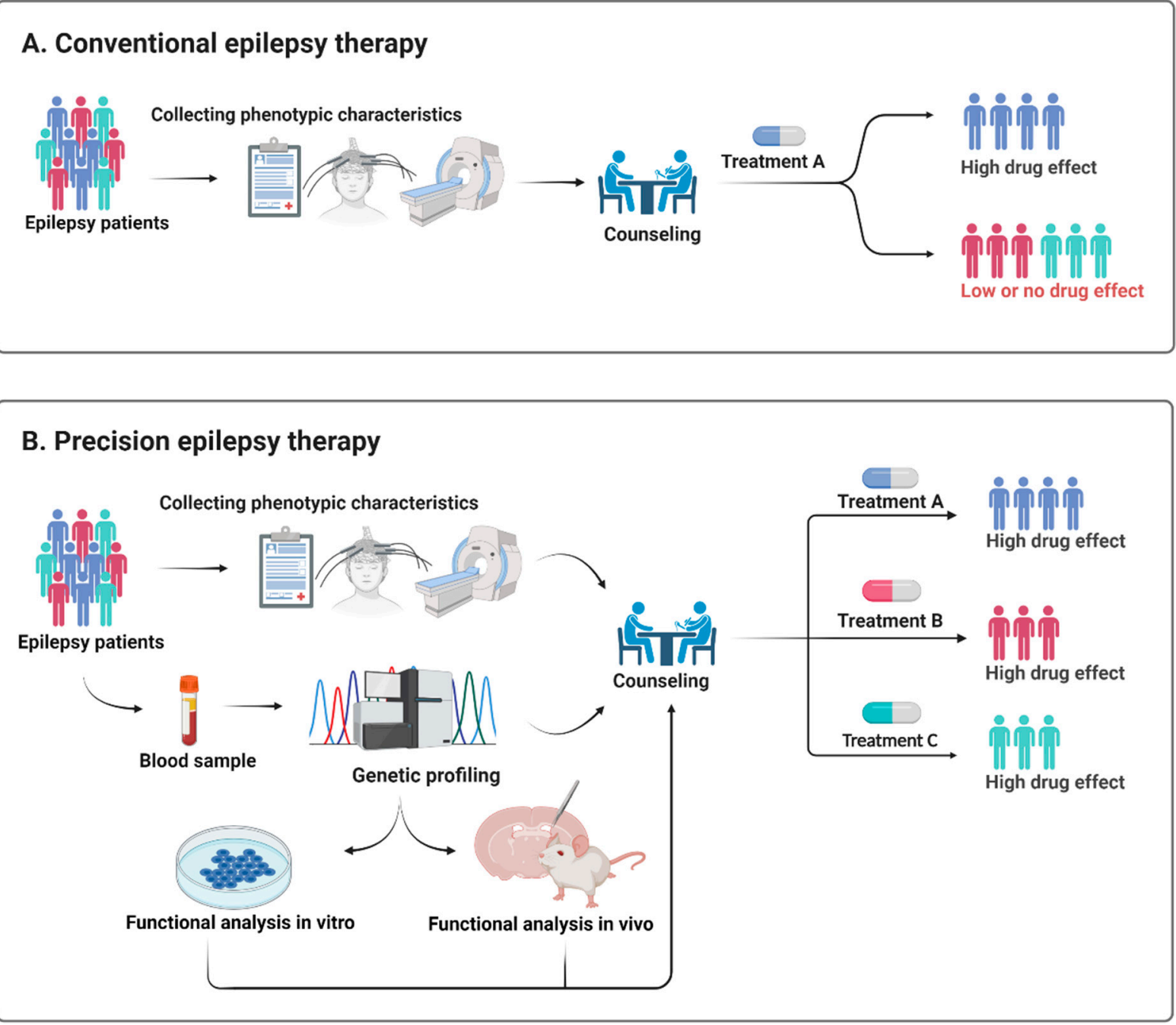

Figure 2. Schematic illustration of how a precision therapy could be applied in epilepsy. Treatment of epilepsy remains largely empirical and rather than the present trial and error approach (A), genetic testing and preclinical in vitro and in vivo models may enable healthcare providers to select a more targeted treatment approach (B).

Ion channel disorders, in particular, have taught us how crucial it is to have insight into the loss-of-function $(\mathrm{LoF})$ versus GoF pathomechanisms when forming therapeutic decisions.

$S C N 1 A$ is a commonly detected epilepsy gene that has an estimated incidence of 1 in 12,200 live births [82]. The most frequent SCN1A-related disorder is DS, and SCN1Adeficiency is also by far the most common genetic cause of DS [64]. In SCN1A-related DS, 
sodium channel blockers such as lamotrigine and carbamazepine should be avoided as they may aggravate seizures, while fenfluramine, cannabidiol, valproic acid, topiramate, clobazam, and stiripentol can be beneficial $[62,83]$.

Another example of precision therapy would be SCN2A-deficiency. GoF SCN2A variants present with seizures within the first 3 months of life-Ohtahara syndrome, EIMFS, and unclassified DEEs at the severe end of the spectrum and BFNIE at the mild end [46]. In contrast, LoF variants either cause non-epilepsy phenotypes such as nonsyndromic intellectual disability, autism, and episodic ataxia or late-onset phenotypes (>3 months of life) including West syndrome, myoclonic atonic epilepsy, and unclassified DEEs [46]. Despite the lack of personalized treatment options in LoF SCN2A cases (other than avoiding sodium channel blockers), GoF variants in $S C N 2 A$ might respond to sodium channel blockers [83,84]. Other examples include ketogenic diet in SLC2A1-deficiency [83], retigabine in LoF KCNQ2- and KCNQ3-related disorders [85], carbamazepine in PRRT2deficiency [83], quinidine in KCNT1-encephalopathies, and ganaxolone in CDKL5- and PCDH19-related disorders $[83,86]$.

A recent study showed that the seizure type at presentation in neonates could suggest a genetic etiology [87]. This was achieved by comparing 20 neonates with a verified genetic epilepsy to 40 neonates with acute provoked seizures [87]. The genetic epilepsies were primarily caused by pathogenic variants in genes encoding ion channels [87]. While neonates with acute provoked seizures often presented with clonic seizures, tonic seizures were mainly associated with channelopathies and were often controlled by sodium channelblockers [87]. This study suggests that early identification of the seizure type can prompt appropriate workup and treatment [87]. It potentially guides treatment while waiting for results of genetic testing, but it also provides a potentially useful tool in countries where the access to genetic testing is currently limited.

At present, disease-specific treatments are only available for a minority of the severe genetic epilepsies and the majority of these are antiseizure medications. Future cuttingedge therapies should target not only seizures but also the developmental outcome and comorbidities [38]. Promising therapies include antisense oligonucleotide (ASO) modulation and, ultimately, gene therapy acting directly on the underlying mechanism that causes the widespread effects of the disorder, as they are likely to be more extensive than those attributed to the epilepsy alone [38]. Two such examples are ASOs used in mice models of $S C N 1 A$ - and SCN8A-encephalopathy and DS [88,89]. An open-label phase 1b/2a trial with an ASO increasing functional SCN1A mRNA and protein expression has recently started and is including subjects with DS second to pathogenic SCN1A variants (https: / / clinicaltrials.gov/ct2/show/NCT04442295, accessed on 22 June 2020 and 4 May 2021). Future clinical trials for genetic therapies must be designed as neurodevelopmental disorder trials rather than epilepsy trials and should reliably measure non-seizure outcomes.

Thus, greater knowledge about genetics and biochemistry is needed amongst healthcare providers before precision medicine approaches can become a part of routine healthcare. In the future, physicians and other healthcare providers will increasingly find themselves needing to interpret the results of genetic tests, understand how that information is relevant to treatment or prevention approaches, and convey this knowledge to subjects.

\section{Genetic Testing in Self-Limiting Epilepsies}

One could argue why early genetic testing and precision diagnosis is needed for self-limiting epilepsies. It is not difficult to imagine the massive toll on parents when their newborns/infants experience convulsions and are hospitalized even in familial cases. Early genetic testing leading to precision diagnosis and an optimal genetic counseling empowers both caregivers and healthcare providers. It provides an explanation and certainty; it enables a more targeted genetic counseling, including knowledge about the prognosis and recurrence risk. This is particularly useful for those with neonatal seizures caused by $K C N Q 2-$ or $K C N Q 3$-deficiency as post-infantile seizures occur in up to $30 \%$ of cases [13]. Furthermore, precision diagnosis allows the subject and families to enter gene-specific 
networks of families with the same genetic condition. Importantly, early genetic testing enables subjects and caregivers to receive tailored treatment and prevent unnecessary and potentially harmful diagnostic procedures and managements. One such example is carbamazepine, which is considered as a precision therapy in PRRT2-deficiency [83].

\section{Conclusions}

Epilepsy syndromes that start in the first year of life display phenotypic and genetic heterogeneity, and genetic testing is crucial for subjects, caregivers, and clinicians. The availability and reduced cost of genetic testing will enable us to make early and accurate diagnosis in pediatric epilepsies, which will inevitably lead to optimized and tailored treatment approaches. Due to the clinical heterogeneity of gene panels targeted at monogenic epilepsies, WES and WGS should be the preferred method compared to a single-gene approach that has limited usefulness in epilepsy genetics. Clinicians will need to consider both the advantages and the pitfalls of the available genetic tests before choosing the path to follow. Early genetic testing enables precision diagnosis and may ultimately lead to a disease-specific treatment.

Author Contributions: Conceptualization, A.B. and M.B.; methodology, software, validation, formal analysis, investigation, resources, data curation, not applicable; writing - original draft preparation, A.B.; writing-review and editing, A.B., M.B., G.R. and R.S.M.; visualization, not applicable; supervision, G.R. and R.S.M.; project administration and funding acquisition, not applicable. All authors have read and agreed to the published version of the manuscript.

Funding: This research received no external funding.

Institutional Review Board Statement: Not applicable.

Informed Consent Statement: Not applicable.

Data Availability Statement: Not applicable.

Acknowledgments: The authors would like to thank the individuals and their families for their participation in our research. The authors thank Claire Gudex for English proofreading of the final draft of the article.

Conflicts of Interest: The authors declare no conflict of interest.

\section{References}

1. Thomas, R.H.; Berkovic, S.F. The hidden genetics of epilepsy-a clinically important new paradigm. Nat. Rev. Neurol. 2014, 10, 283-292. [CrossRef] [PubMed]

2. Hebbar, M.; Mefford, H.C. Recent advances in epilepsy genomics and genetic testing. F1000Research 2020, 9, 185. [CrossRef] [PubMed]

3. Howell, K.B.; Freeman, J.L.; Mackay, M.T.; Fahey, M.C.; Archer, J.; Berkovic, S.F.; Chan, E.; Dabscheck, G.; Eggers, S.; Hayman, M.; et al. The severe epilepsy syndromes of infancy: A population-based study. Epilepsia 2021, 62, 358-370. [CrossRef]

4. Moller, R.S.; Larsen, L.H.; Johannesen, K.M.; Talvik, I.; Talvik, T.; Vaher, U.; Miranda, M.J.; Farooq, M.; Nielsen, J.E.; Svendsen, L.L.; et al. Gene Panel Testing in Epileptic Encephalopathies and Familial Epilepsies. Mol. Syndromol. 2016, 7, 210-219. [CrossRef]

5. Hartley, T.; Lemire, G.; Kernohan, K.D.; Howley, H.E.; Adams, D.R.; Boycott, K.M. New Diagnostic Approaches for Undiagnosed Rare Genetic Diseases. Annu. Rev. Genom. Hum. Genet. 2020, 21, 351-372. [CrossRef]

6. Kotsopoulos, I.A.; van Merode, T.; Kessels, F.G.; de Krom, M.C.; Knottnerus, J.A. Systematic review and meta-analysis of incidence studies of epilepsy and unprovoked seizures. Epilepsia 2002, 43, 1402-1409. [CrossRef]

7. Lee, E.H. Epilepsy syndromes during the first year of life and the usefulness of an epilepsy gene panel. Korean J. Pediatr. 2018, 61, 101-107. [CrossRef]

8. Singh, R.; Scheffer, I.E.; Crossland, K.; Berkovic, S.F. Generalized epilepsy with febrile seizures plus: A common childhood-onset genetic epilepsy syndrome. Ann. Neurol. 1999, 45, 75-81. [CrossRef]

9. Verrotti, A.; Matricardi, S.; Pavone, P.; Marino, R.; Curatolo, P. Reflex myoclonic epilepsy in infancy: A critical review. Epileptic Disord. 2013, 15, 114-122. [CrossRef] [PubMed]

10. Miceli, F.; Soldovieri, M.V.; Joshi, N.; Weckhuysen, S.; Cooper, E.; Taglialatela, M. KCNQ2-Related Disorders. In GeneReviews((R)); Adam, M.P., Ardinger, H.H., Pagon, R.A., Wallace, S.E., Bean, L.J.H., Stephens, K., Amemiya, A., Eds.; University of Washington: Seattle, WA, USA, 1993. 
11. Singh, N.A.; Charlier, C.; Stauffer, D.; DuPont, B.R.; Leach, R.J.; Melis, R.; Ronen, G.M.; Bjerre, I.; Quattlebaum, T.; Murphy, J.V.; et al. A novel potassium channel gene, KCNQ2, is mutated in an inherited epilepsy of newborns. Nat. Genet. 1998, 18, 25-29. [CrossRef] [PubMed]

12. Ronen, G.M.; Rosales, T.O.; Connolly, M.; Anderson, V.E.; Leppert, M. Seizure characteristics in chromosome 20 benign familial neonatal convulsions. Neurology 1993, 43, 1355-1360. [CrossRef]

13. Grinton, B.E.; Heron, S.E.; Pelekanos, J.T.; Zuberi, S.M.; Kivity, S.; Afawi, Z.; Williams, T.C.; Casalaz, D.M.; Yendle, S.; Linder, I.; et al. Familial neonatal seizures in 36 families: Clinical and genetic features correlate with outcome. Epilepsia 2015, 56, 1071-1080. [CrossRef] [PubMed]

14. Scalmani, P.; Rusconi, R.; Armatura, E.; Zara, F.; Avanzini, G.; Franceschetti, S.; Mantegazza, M. Effects in neocortical neurons of mutations of the $\mathrm{Na}(\mathrm{v}) 1.2 \mathrm{Na}+$ channel causing benign familial neonatal-infantile seizures. J. Neurosci. 2006, 26, 10100-10109. [CrossRef] [PubMed]

15. Heron, S.E.; Crossland, K.M.; Andermann, E.; Phillips, H.A.; Hall, A.J.; Bleasel, A.; Shevell, M.; Mercho, S.; Seni, M.H.; Guiot, M.C.; et al. Sodium-channel defects in benign familial neonatal-infantile seizures. Lancet 2002, 360, 851-852. [CrossRef]

16. Vigevano, F.; Fusco, L.; Di Capua, M.; Ricci, S.; Sebastianelli, R.; Lucchini, P. Benign infantile familial convulsions. Eur. J. Pediatr. 1992, 151, 608-612. [CrossRef] [PubMed]

17. Mulley, J.C.; Heron, S.E.; Dibbens, L.M. Proposed genetic classification of the "benign" familial neonatal and infantile epilepsies. Epilepsia 2011, 52, 649-650. [CrossRef]

18. Nobile, C.; Striano, P. PRRT2: A major cause of infantile epilepsy and other paroxysmal disorders of childhood. Prog. Brain Res. 2014, 213, 141-158. [CrossRef] [PubMed]

19. Ono, S.; Yoshiura, K.; Kinoshita, A.; Kikuchi, T.; Nakane, Y.; Kato, N.; Sadamatsu, M.; Konishi, T.; Nagamitsu, S.; Matsuura, M.; et al. Mutations in PRRT2 responsible for paroxysmal kinesigenic dyskinesias also cause benign familial infantile convulsions. J. Hum. Genet. 2012, 57, 338-341. [CrossRef]

20. Zeng, Q.; Zhang, Y.H.; Yang, X.L.; Pu, L.H.; Zhang, J.; Liu, A.J.; Yang, Z.X.; Liu, X.Y.; Wu, X.R. Spectrum of mutations in benign familial neonatal-infantile epilepsy. Zhonghua Er Ke Za Zhi Chin. J. Pediatr. 2018, 56, 267-273. [CrossRef]

21. Schubert, J.; Paravidino, R.; Becker, F.; Berger, A.; Bebek, N.; Bianchi, A.; Brockmann, K.; Capovilla, G.; Dalla Bernardina, B.; Fukuyama, Y.; et al. PRRT2 mutations are the major cause of benign familial infantile seizures. Hum. Mutat. 2012, 33, 1439-1443. [CrossRef] [PubMed]

22. Heron, S.E.; Grinton, B.E.; Kivity, S.; Afawi, Z.; Zuberi, S.M.; Hughes, J.N.; Pridmore, C.; Hodgson, B.L.; Iona, X.; Sadleir, L.G.; et al. PRRT2 mutations cause benign familial infantile epilepsy and infantile convulsions with choreoathetosis syndrome. Am. J. Hum. Genet. 2012, 90, 152-160. [CrossRef]

23. Yang, X.; Zhang, Y.; Xu, X.; Wang, S.; Yang, Z.; Wu, Y.; Liu, X.; Wu, X. Phenotypes and PRRT2 mutations in Chinese families with benign familial infantile epilepsy and infantile convulsions with paroxysmal choreoathetosis. BMC Neurol. 2013, 13, 209. [CrossRef] [PubMed]

24. Yang, X.; Zhang, Y.; Xu, X.; Yu, X.; Zhang, X.; Yang, Z.; Wang, S.; Wu, Y.; Liu, X.; Wu, X. Phenotypes and PRRT2 mutation analysis in families with benign familial infantile epilepsy. Zhonghua Er Ke Za Zhi Chin. J. Pediatr. 2014, 52, 806-811.

25. Valente, P.; Castroflorio, E.; Rossi, P.; Fadda, M.; Sterlini, B.; Cervigni, R.I.; Prestigio, C.; Giovedi, S.; Onofri, F.; Mura, E.; et al. PRRT2 Is a Key Component of the Ca(2+)-Dependent Neurotransmitter Release Machinery. Cell Rep. 2016, 15, 117-131. [CrossRef] [PubMed]

26. Gardella, E.; Moller, R.S. Phenotypic and genetic spectrum of SCN8A-related disorders, treatment options, and outcomes. Epilepsia 2019, 60 (Suppl. 3), S77-S85. [CrossRef] [PubMed]

27. Scheffer, I.E.; Berkovic, S.F. Generalized epilepsy with febrile seizures plus. A genetic disorder with heterogeneous clinical phenotypes. Brain 1997, 120, 479-490. [CrossRef]

28. Myers, K.A.; Scheffer, I.E.; Berkovic, S.F.; Commission, I.G. Genetic literacy series: Genetic epilepsy with febrile seizures plus. Epileptic Disord. 2018, 20, 232-238. [CrossRef] [PubMed]

29. Zhang, Y.H.; Burgess, R.; Malone, J.P.; Glubb, G.C.; Helbig, K.L.; Vadlamudi, L.; Kivity, S.; Afawi, Z.; Bleasel, A.; Grattan-Smith, P.; et al. Genetic epilepsy with febrile seizures plus: Refining the spectrum. Neurology 2017, 89, 1210-1219. [CrossRef]

30. Moller, R.S.; Wuttke, T.V.; Helbig, I.; Marini, C.; Johannesen, K.M.; Brilstra, E.H.; Vaher, U.; Borggraefe, I.; Talvik, I.; Talvik, T.; et al. Mutations in GABRB3: From febrile seizures to epileptic encephalopathies. Neurology 2017, 88, 483-492. [CrossRef]

31. Johannesen, K.; Marini, C.; Pfeffer, S.; Moller, R.S.; Dorn, T.; Niturad, C.E.; Gardella, E.; Weber, Y.; Sondergard, M.; Hjalgrim, H.; et al. Phenotypic spectrum of GABRA1: From generalized epilepsies to severe epileptic encephalopathies. Neurology 2016, 87, 1140-1151. [CrossRef] [PubMed]

32. Wolking, S.; May, P.; Mei, D.; Moller, R.S.; Balestrini, S.; Helbig, K.L.; Altuzarra, C.D.; Chatron, N.; Kaiwar, C.; Stohr, K.; et al. Clinical spectrum of STX1B-related epileptic disorders. Neurology 2019, 92, e1238-e1249. [CrossRef] [PubMed]

33. Goldberg-Stern, H.; Aharoni, S.; Afawi, Z.; Bennett, O.; Appenzeller, S.; Pendziwiat, M.; Kuhlenbaumer, G.; Basel-Vanagaite, L.; Shuper, A.; Korczyn, A.D.; et al. Broad phenotypic heterogeneity due to a novel SCN1A mutation in a family with genetic epilepsy with febrile seizures plus. J. Child Neurol. 2014, 29, 221-226. [CrossRef] [PubMed]

34. Auvin, S.; Pandit, F.; De Bellecize, J.; Badinand, N.; Isnard, H.; Motte, J.; Villeneuve, N.; Lamblin, M.D.; Vallee, L. Benign myoclonic epilepsy in infants: Electroclinical features and long-term follow-up of 34 patients. Epilepsia 2006, 47, 387-393. [CrossRef] 
35. Scheffer, I.E.; Liao, J. Deciphering the concepts behind "Epileptic encephalopathy" and "Developmental and epileptic encephalopathy". Eur. J. Paediatr. Neurol. 2020, 24, 11-14. [CrossRef]

36. Scheffer, I.E.; Berkovic, S.; Capovilla, G.; Connolly, M.B.; French, J.; Guilhoto, L.; Hirsch, E.; Jain, S.; Mathern, G.W.; Moshe, S.L.; et al. ILAE classification of the epilepsies: Position paper of the ILAE Commission for Classification and Terminology. Epilepsia 2017, 58, 512-521. [CrossRef] [PubMed]

37. Scheffer, I.E.; Berkovic, S.F. The genetics of human epilepsy. Trends Pharmacol. Sci. 2003, 24, 428-433. [CrossRef]

38. McTague, A.; Howell, K.B.; Cross, J.H.; Kurian, M.A.; Scheffer, I.E. The genetic landscape of the epileptic encephalopathies of infancy and childhood. Lancet Neurol. 2016, 15, 304-316. [CrossRef]

39. Olson, H.E.; Kelly, M.; LaCoursiere, C.M.; Pinsky, R.; Tambunan, D.; Shain, C.; Ramgopal, S.; Takeoka, M.; Libenson, M.H.; Julich, K.; et al. Genetics and genotype-phenotype correlations in early onset epileptic encephalopathy with burst suppression. Ann. Neurol. 2017, 81, 419-429. [CrossRef]

40. Beal, J.C.; Cherian, K.; Moshe, S.L. Early-onset epileptic encephalopathies: Ohtahara syndrome and early myoclonic encephalopathy. Pediatr. Neurol. 2012, 47,317-323. [CrossRef]

41. Ohtahara, S.; Yamatogi, Y. Ohtahara syndrome: With special reference to its developmental aspects for differentiating from early myoclonic encephalopathy. Epilepsy Res. 2006, 70 (Suppl. 1), S58-S67. [CrossRef]

42. Yamatogi, Y.; Ohtahara, S. Early-infantile epileptic encephalopathy with suppression-bursts, Ohtahara syndrome; its overview referring to our 16 cases. Brain Dev. 2002, 24, 13-23. [CrossRef]

43. Fusco, L.; Pachatz, C.; Di Capua, M.; Vigevano, F. Video/EEG aspects of early-infantile epileptic encephalopathy with suppressionbursts (Ohtahara syndrome). Brain Dev. 2001, 23, 708-714. [CrossRef]

44. Milh, M.; Villeneuve, N.; Chouchane, M.; Kaminska, A.; Laroche, C.; Barthez, M.A.; Gitiaux, C.; Bartoli, C.; Borges-Correia, A.; Cacciagli, P.; et al. Epileptic and nonepileptic features in patients with early onset epileptic encephalopathy and STXBP1 mutations. Epilepsia 2011, 52, 1828-1834. [CrossRef]

45. Weckhuysen, S.; Mandelstam, S.; Suls, A.; Audenaert, D.; Deconinck, T.; Claes, L.R.; Deprez, L.; Smets, K.; Hristova, D.; Yordanova, I.; et al. KCNQ2 encephalopathy: Emerging phenotype of a neonatal epileptic encephalopathy. Ann. Neurol. 2012, 71, 15-25. [CrossRef] [PubMed]

46. Wolff, M.; Johannesen, K.M.; Hedrich, U.B.S.; Masnada, S.; Rubboli, G.; Gardella, E.; Lesca, G.; Ville, D.; Milh, M.; Villard, L.; et al. Genetic and phenotypic heterogeneity suggest therapeutic implications in SCN2A-related disorders. Brain 2017, 140, 1316-1336. [CrossRef] [PubMed]

47. Kato, M.; Saitoh, S.; Kamei, A.; Shiraishi, H.; Ueda, Y.; Akasaka, M.; Tohyama, J.; Akasaka, N.; Hayasaka, K. A longer polyalanine expansion mutation in the ARX gene causes early infantile epileptic encephalopathy with suppression-burst pattern (Ohtahara syndrome). Am. J. Hum. Genet. 2007, 81, 361-366. [CrossRef] [PubMed]

48. Molinari, F.; Kaminska, A.; Fiermonte, G.; Boddaert, N.; Raas-Rothschild, A.; Plouin, P.; Palmieri, L.; Brunelle, F.; Palmieri, F.; Dulac, O.; et al. Mutations in the mitochondrial glutamate carrier SLC25A22 in neonatal epileptic encephalopathy with suppression bursts. Clin. Genet. 2009, 76, 188-194. [CrossRef]

49. Gertler, T.; Bearden, D.; Bhattacharjee, A.; Carvill, G. KCNT1-Related Epilepsy. In GeneReviews((R)); Adam, M.P., Ardinger, H.H., Pagon, R.A., Wallace, S.E., Bean, L.J.H., Stephens, K., Amemiya, A., Eds.; University of Washington: Seattle, WA, USA, 1993.

50. Borlot, F.; Abushama, A.; Morrison-Levy, N.; Jain, P.; Puthenveettil Vinayan, K.; Abukhalid, M.; Aldhalaan, H.M.; Almuzaini, H.S.; Gulati, S.; Hershkovitz, T.; et al. KCNT1-related epilepsy: An international multicenter cohort of 27 pediatric cases. Epilepsia 2020, 61, 679-692. [CrossRef] [PubMed]

51. Zhou, X.; Ma, A.; Liu, X.; Huang, C.; Zhang, Y.; Shi, R.; Mao, S.; Geng, T.; Li, S. Infantile seizures and other epileptic phenotypes in a Chinese family with a missense mutation of KCNQ2. Eur. J. Pediatr. 2006, 165, 691-695. [CrossRef]

52. Shi, X.; Yasumoto, S.; Kurahashi, H.; Nakagawa, E.; Fukasawa, T.; Uchiya, S.; Hirose, S. Clinical spectrum of SCN2A mutations. Brain Dev. 2012, 34, 541-545. [CrossRef]

53. Murakami, N.; Ohtsuka, Y.; Ohtahara, S. Early infantile epileptic syndromes with suppression-bursts: Early myoclonic encephalopathy vs. Ohtahara syndrome. Jpn. J. Psychiatry Neurol. 1993, 47, 197-200. [CrossRef] [PubMed]

54. Bayat, A.; Knaus, A.; Pendziwiat, M.; Afenjar, A.; Barakat, T.S.; Bosch, F.; Callewaert, B.; Calvas, P.; Ceulemans, B.; Chassaing, N.; et al. Lessons learned from 40 novel PIGA patients and a review of the literature. Epilepsia 2020, 61, 1142-1155. [CrossRef]

55. Kato, M.; Saitsu, H.; Murakami, Y.; Kikuchi, K.; Watanabe, S.; Iai, M.; Miya, K.; Matsuura, R.; Takayama, R.; Ohba, C.; et al. PIGA mutations cause early-onset epileptic encephalopathies and distinctive features. Neurology 2014, 82, 1587-1596. [CrossRef] [PubMed]

56. Hansen, J.; Snow, C.; Tuttle, E.; Ghoneim, D.H.; Yang, C.S.; Spencer, A.; Gunter, S.A.; Smyser, C.D.; Gurnett, C.A.; Shinawi, M.; et al. De novo mutations in SIK1 cause a spectrum of developmental epilepsies. Am. J. Hum. Genet. 2015, 96, 682-690. [CrossRef] [PubMed]

57. O'Callaghan, F.J.; Lux, A.L.; Darke, K.; Edwards, S.W.; Hancock, E.; Johnson, A.L.; Kennedy, C.R.; Newton, R.W.; Verity, C.M.; Osborne, J.P. The effect of lead time to treatment and of age of onset on developmental outcome at 4 years in infantile spasms: Evidence from the United Kingdom Infantile Spasms Study. Epilepsia 2011, 52, 1359-1364. [CrossRef] [PubMed]

58. Pavone, P.; Striano, P.; Falsaperla, R.; Pavone, L.; Ruggieri, M. Infantile spasms syndrome, West syndrome and related phenotypes: What we know in 2013. Brain Dev. 2014, 36, 739-751. [CrossRef] 
59. Muir, A.M.; Myers, C.T.; Nguyen, N.T.; Saykally, J.; Craiu, D.; De Jonghe, P.; Helbig, I.; Hoffman-Zacharska, D.; Guerrini, R.; Lehesjoki, A.E.; et al. Genetic heterogeneity in infantile spasms. Epilepsy Res. 2019, 156, 106181. [CrossRef]

60. Michaud, J.L.; Lachance, M.; Hamdan, F.F.; Carmant, L.; Lortie, A.; Diadori, P.; Major, P.; Meijer, I.A.; Lemyre, E.; Cossette, P.; et al. The genetic landscape of infantile spasms. Hum. Mol. Genet. 2014, 23, 4846-4858. [CrossRef]

61. Boutry-Kryza, N.; Labalme, A.; Ville, D.; de Bellescize, J.; Touraine, R.; Prieur, F.; Dimassi, S.; Poulat, A.L.; Till, M.; Rossi, M.; et al. Molecular characterization of a cohort of 73 patients with infantile spasms syndrome. Eur. J. Med. Genet. 2015, 58, 51-58. [CrossRef]

62. Samanta, D. Changing Landscape of Dravet Syndrome Management: An Overview. Neuropediatrics 2020, 51, 135-145. [CrossRef]

63. Dravet, C.; Bureau, M.; Oguni, H.; Fukuyama, Y.; Cokar, O. Severe myoclonic epilepsy in infancy: Dravet syndrome. Adv. Neurol. 2005, 95, 71-102. [PubMed]

64. Steel, D.; Symonds, J.D.; Zuberi, S.M.; Brunklaus, A. Dravet syndrome and its mimics: Beyond SCN1A. Epilepsia 2017, 58, 1807-1816. [CrossRef] [PubMed]

65. Burgess, R.; Wang, S.; McTague, A.; Boysen, K.E.; Yang, X.; Zeng, Q.; Myers, K.A.; Rochtus, A.; Trivisano, M.; Gill, D.; et al. The Genetic Landscape of Epilepsy of Infancy with Migrating Focal Seizures. Ann. Neurol. 2019, 86, 821-831. [CrossRef] [PubMed]

66. Koutroumanidis, M.; Arzimanoglou, A.; Caraballo, R.; Goyal, S.; Kaminska, A.; Laoprasert, P.; Oguni, H.; Rubboli, G.; Tatum, W.; Thomas, P.; et al. The role of EEG in the diagnosis and classification of the epilepsy syndromes: A tool for clinical practice by the ILAE Neurophysiology Task Force (Part 2). Epileptic Disord. 2017, 19, 385-437. [CrossRef]

67. Yoshitomi, S.; Takahashi, Y.; Imai, K.; Koshimizu, E.; Miyatake, S.; Nakashima, M.; Saitsu, H.; Matsumoto, N.; Kato, M.; Fujita, T.; et al. Different types of suppression-burst patterns in patients with epilepsy of infancy with migrating focal seizures (EIMFS). Seizure 2019, 65, 118-123. [CrossRef] [PubMed]

68. Bonardi, C.M.; Heyne, H.O.; Fiannacca, M.; Fitzgerald, M.P.; Gardella, E.; Gunning, B.; Olofsson, K.; Lesca, G.; Verbeek, N.; Stamberger, H.; et al. KCNT1-related epilepsies and epileptic encephalopathies: Phenotypic and mutational spectrum. Brain 2021. [CrossRef]

69. Lindy, A.S.; Stosser, M.B.; Butler, E.; Downtain-Pickersgill, C.; Shanmugham, A.; Retterer, K.; Brandt, T.; Richard, G.; McKnight, D.A. Diagnostic outcomes for genetic testing of 70 genes in 8565 patients with epilepsy and neurodevelopmental disorders. Epilepsia 2018, 59, 1062-1071. [CrossRef]

70. Mercimek-Mahmutoglu, S.; Patel, J.; Cordeiro, D.; Hewson, S.; Callen, D.; Donner, E.J.; Hahn, C.D.; Kannu, P.; Kobayashi, J.; Minassian, B.A.; et al. Diagnostic yield of genetic testing in epileptic encephalopathy in childhood. Epilepsia 2015, 56, 707-716. [CrossRef]

71. Ortega-Moreno, L.; Giraldez, B.G.; Soto-Insuga, V.; Losada-Del Pozo, R.; Rodrigo-Moreno, M.; Alarcon-Morcillo, C.; SanchezMartin, G.; Diaz-Gomez, E.; Guerrero-Lopez, R.; Serratosa, J.M.; et al. Molecular diagnosis of patients with epilepsy and developmental delay using a customized panel of epilepsy genes. PLoS ONE 2017, 12, e0188978. [CrossRef]

72. Snoeijen-Schouwenaars, F.M.; van Ool, J.S.; Verhoeven, J.S.; van Mierlo, P.; Braakman, H.M.H.; Smeets, E.E.; Nicolai, J.; Schoots, J.; Teunissen, M.W.A.; Rouhl, R.P.W.; et al. Diagnostic exome sequencing in 100 consecutive patients with both epilepsy and intellectual disability. Epilepsia 2019, 60, 155-164. [CrossRef]

73. Costain, G.; Cordeiro, D.; Matviychuk, D.; Mercimek-Andrews, S. Clinical Application of Targeted Next-Generation Sequencing Panels and Whole Exome Sequencing in Childhood Epilepsy. Neuroscience 2019, 418, 291-310. [CrossRef]

74. Helbig, K.L.; Farwell Hagman, K.D.; Shinde, D.N.; Mroske, C.; Powis, Z.; Li, S.; Tang, S.; Helbig, I. Diagnostic exome sequencing provides a molecular diagnosis for a significant proportion of patients with epilepsy. Genet. Med. 2016, 18, 898-905. [CrossRef] [PubMed]

75. Mefford, H.C.; Yendle, S.C.; Hsu, C.; Cook, J.; Geraghty, E.; McMahon, J.M.; Eeg-Olofsson, O.; Sadleir, L.G.; Gill, D.; Ben-Zeev, B.; et al. Rare copy number variants are an important cause of epileptic encephalopathies. Ann. Neurol. 2011, 70, 974-985. [CrossRef] [PubMed]

76. Karczewski, K.J.; Francioli, L.C.; Tiao, G.; Cummings, B.B.; Alfoldi, J.; Wang, Q.; Collins, R.L.; Laricchia, K.M.; Ganna, A.; Birnbaum, D.P.; et al. The mutational constraint spectrum quantified from variation in 141,456 humans. Nature 2020, 581, 434-443. [CrossRef] [PubMed]

77. Landrum, M.J.; Kattman, B.L. ClinVar at five years: Delivering on the promise. Hum. Mutat. 2018, 39, 1623-1630. [CrossRef] [PubMed]

78. Moller, R.S.; Hammer, T.B.; Rubboli, G.; Lemke, J.R.; Johannesen, K.M. From next-generation sequencing to targeted treatment of non-acquired epilepsies. Expert Rev. Mol. Diagn. 2019, 19, 217-228. [CrossRef] [PubMed]

79. Zacher, P.; Mayer, T.; Brandhoff, F.; Bartolomaeus, T.; Le Duc, D.; Finzel, M.; Heinze, A.; Horn, S.; Klockner, C.; Korber, G.; et al. The genetic landscape of intellectual disability and epilepsy in adults and the elderly: A systematic genetic work-up of 150 individuals. Genet. Med. 2021. [CrossRef]

80. Johannesen, K.M.; Nikanorova, N.; Marjanovic, D.; Pavbro, A.; Larsen, L.H.G.; Rubboli, G.; Moller, R.S. Utility of genetic testing for therapeutic decision-making in adults with epilepsy. Epilepsia 2020, 61, 1234-1239. [CrossRef] [PubMed]

81. Brunklaus, A.; Schorge, S.; Smith, A.D.; Ghanty, I.; Stewart, K.; Gardiner, S.; Du, J.; Perez-Palma, E.; Symonds, J.D.; Collier, A.C.; et al. SCN1A variants from bench to bedside-improved clinical prediction from functional characterization. Hum. Mutat. 2020, 41, 363-374. [CrossRef] 
82. Symonds, J.D.; Zuberi, S.M.; Stewart, K.; McLellan, A.; O’Regan, M.; MacLeod, S.; Jollands, A.; Joss, S.; Kirkpatrick, M.; Brunklaus, A.; et al. Incidence and phenotypes of childhood-onset genetic epilepsies: A prospective population-based national cohort. Brain 2019, 142, 2303-2318. [CrossRef]

83. Helbig, I.; Ellis, C.A. Personalized medicine in genetic epilepsies-Possibilities, challenges, and new frontiers. Neuropharmacology 2020, 172, 107970. [CrossRef] [PubMed]

84. Sanders, S.J.; Campbell, A.J.; Cottrell, J.R.; Moller, R.S.; Wagner, F.F.; Auldridge, A.L.; Bernier, R.A.; Catterall, W.A.; Chung, W.K.; Empfield, J.R.; et al. Progress in Understanding and Treating SCN2A-Mediated Disorders. Trends Neurosci. 2018, 41, 442-456. [CrossRef] [PubMed]

85. Millichap, J.J.; Park, K.L.; Tsuchida, T.; Ben-Zeev, B.; Carmant, L.; Flamini, R.; Joshi, N.; Levisohn, P.M.; Marsh, E.; Nangia, S.; et al. KCNQ2 encephalopathy: Features, mutational hot spots, and ezogabine treatment of 11 patients. Neurol. Genet. 2016, 2, e96. [CrossRef]

86. Bialer, M.; Johannessen, S.I.; Koepp, M.J.; Levy, R.H.; Perucca, E.; Perucca, P.; Tomson, T.; White, H.S. Progress report on new antiepileptic drugs: A summary of the Fifteenth Eilat Conference on New Antiepileptic Drugs and Devices (EILAT XV). II. Drugs in more advanced clinical development. Epilepsia 2020, 61, 2365-2385. [CrossRef]

87. Cornet, M.C.; Morabito, V.; Lederer, D.; Glass, H.C.; Ferrao Santos, S.; Numis, A.L.; Ferriero, D.M.; Sands, T.T.; Cilio, M.R. Neonatal presentation of genetic epilepsies: Early differentiation from acute provoked seizures. Epilepsia 2021. [CrossRef] [PubMed]

88. Han, Z.; Chen, C.; Christiansen, A.; Ji, S.; Lin, Q.; Anumonwo, C.; Liu, C.; Leiser, S.C.; Aznarez, I.; Liau, G.; et al. Antisense oligonucleotides increase Scn1a expression and reduce seizures and SUDEP incidence in a mouse model of Dravet syndrome. Sci. Transl. Med. 2020, 12, eaaz6100. [CrossRef]

89. Lenk, G.M.; Jafar-Nejad, P.; Hill, S.F.; Huffman, L.D.; Smolen, C.E.; Wagnon, J.L.; Petit, H.; Yu, W.; Ziobro, J.; Bhatia, K.; et al. Scn8a Antisense Oligonucleotide Is Protective in Mouse Models of SCN8A Encephalopathy and Dravet Syndrome. Ann. Neurol. 2020, 87, 339-346. [CrossRef] 